\title{
Merebut Sekolah Turki: Represi Transnasional Rezim Islamis dan Pembersihan Sekolah Gülen di Indonesia
}

\author{
${ }^{1 *}$ Yusli Effendi
}

${ }^{1}$ Departemen Hubungan Internasional, Universitas Brawijaya, Indonesia

\begin{abstract}
This paper seeks to address Erdoğan's transnational repression towards Turkish citizens and Gülen-linked schools in Indonesia which are denounced as part of Fethullahç1 Terör Örgütü/Fethullah Gülen Terror Organization (FETÖ)'s most vital source of funding. It is argued that the AKP-ruled government effectively transferred political hostilities from authoritarian Turkey to democratic Indonesia in micro-level targeting Turkish Gülenist teachers and other Hizmet Movement adherents. In exercising extraterritorial coercive acts, the regime relied on institutional outposts such as the embassy, consulate, and mission. These proxy regime institutions played an agressive role in the repression of the Turkish diaspora, including active surveillance, nationality deprivation, and intimidation of the dissent's family members. They also have tried to shut down, take control, or take over nine Indonesia's Gülenlinked educational institutions to The Maarif Foundation (TMF). Nevertheless, in this mesolevel (the Gülen Movement as a transnational network), The Turkish Government have failed to purge Gülen-linked schools whose their cooperation with PASIAD—which is associated with FETO-was terminated in 2015. Employing qualitative approach and data combined with content analysis, this study contributes in explaining Erdoğan regime's coercive power across border which meets its middle power counterpart. One of the more significant findings to emerge from this study is that extraterritorial repressive acts were hindered by the national law and sovereignty of political opponents' host country.
\end{abstract}

Keywords: transnational repression, authoritarianism beyond state, Gülen Movement, Indonesia's Turkish schools

\section{Latar Belakang Riset}

Kegagalan kudeta militer 15 Juli 2016 yang dilakukan faksi kecil Angkatan Bersenjata Turki (TSK) dimanfaatkan oleh Presiden Erdoğan untuk bertindak semakin keras terhadap lawan politiknya yang utama, Gerakan

* Corresponding author: Yusli Effendi

mfaishal@ub.ac.id

Published online at

https://islamicinsights.ub.ac.id/index.php/insights/issue/view/3

Copyright (c) 2019 PSP2M UB Publishing. All Rights Reserved
Gülen. Upaya Kudeta 15 Juli merupakan peristiwa keempat dan puncak dari tiga peristiwa kunci yang membentuk Turki saat ini (Journalists and Writers Foundation, 2019). Tiga kejadian kunci lainnya ialah demonstrasi Gezi Park 2013, skandal korupsi Desember 2015, dan kegagalan negosiasi damai 2015. Usai Musim Semi Arab 2011, Rezim Erdoğan secara gradual melakukan sentralisasi kekuasaan dengan 
mengorbankan nilai-nilai demokrasi, Hak Asasi Manusia (HAM), perdamaian dan stabilitas. Keempat peristiwa kunci berkulminasi pada pengukuhan otoritarianisme Rezim Erdoğan melalui amandemen Kontitusi yang memberikan presiden kekuasaan luar biasa-paskareferendum 16 April 2017_-dan mentransformasi Turki dari negara demokrasi parlementer ke negara bersistem presidensial.

Upaya Kudeta 15 Juli yang gagal juga merubah secara dramatis kebijakan dalam negeri dan luar negeri Turki. Akibat pembersihan besarbesaran kelompok yang dianggap tak loyal oleh Pemerintah, di dalam negeri tercipta koalisi kekuatan politik baru. Sementara dari kebijakan luar negeri muncul sikap anti-Barat, khususnya antiAmerika (Yavuz \& Koç, 2016). Pembersihan elemen yang tak setia pada pemerintah terjadi di institusi militer, kepolisian, intelijen, publik, pendidikan, hingga kelompok masyarakat. Gerakan Gülen - atau Gerakan Hizmet Gülenpun secara resmi ditetapkan sebagai kelompok teroris Fethullah Gülen Terror Organization (FETO). Tak berhenti disitu, sebagai bagian upaya menciptakan negara dalam kondisi darurat, Erdoğan merilis Dekrit No.KHK/667 pada 22 Juli 2016 yang melarang seluruh "lembaga dan organisasi pendidikan privat serta asrama dan penginapan pelajar privat yang terkait, terafiliasi, atau terhubung dengan apa yang disebut pemerintah sebagai pro-Fethullah (Gülenist) Terrorist Organization (FETO/PDY)" (European Commission for Democracy Through Law, 2016). Kantor Berita Pemerintah, Anadolu Agency, merilis jumlah masif para tentara, polisi, jaksa, hakim, serta penduduk sipil ditahan yang mencapai 18.756 orang dan yang ditangkap hingga 10.192 orang. Kudeta 15 Juli menelan korban 238 jiwa dengan 171 dari penduduk sipil dan selebihnya aparat keamanan (Anadolu Agency, 2016).

Tak hanya di dalam negeri, Erdoğan juga memburu dan merepresi seluruh pendukung Gerakan Hizmet di luar negeri. Erdoğan mempersekusi para pengkritiknya — utamanya Gülenis-di luar negeri menggunakan lembaga pemerintahan maupun NGO bayangan yang pro-rezim. Untuk upaya ini, Pemerintah Turki banyak melakukan pelanggaran HAM dengan melakukan penculikan, serangan dan kekerasan fisik, profiling, diskriminasi, kejahatan kebencian, hingga di luar batas negaranya. Pengabaian hukum internasional, intervensi urusan dalam negeri negara lain, hingga pelanggaran hukum nasional, memunculkan ketegangan dan permasalahan hubungan antarpemerintah. Institusi yang terlibat ialah National Intelligence Organization (MIT), the Overseas Turks and Kin Communities Agency (YTB), the Turkish Cooperation and Development Agency (TIKA), the Religious Affairs Directorate (Diyanet), the Anadolu News Agency, the Turkish Radio and Television Corporation (TRT), the Yunus Emre Institute, dan the Maarif Foundation (Stockholm Center for Freedom, 2017).

Jejaring global Gerakan Gülen memaksa Pemerintah Turki melakukan represi ekstrateritorial setelah terlebih dahulu secara sistematis menstigmanya sebagai "kelompok teror", "ancaman keamanan nasional" dan "ancaman internasional". Kepolisian Turki bahkan melabeli FETO sebagai "organisasi 
teror dan kejahatan internasional" karena Gerakan Gülen memiliki 2000 lembaga pendidikan dan terentang luas di 160 negara (Turkish National Police Academy, 2019). Pemerintah Turki memobilisasi kekuatan diplomatik, ekonomi, dan politik untuk memburu aktivis Gülen, meminta pemerintah negara lain memenjarakan atau mendeportasi mereka, serta meminta mereka menutup sekolah-sekolahnya. Berdasarkan sumber anonim Kemenlu Turki, dari 15 Juli hingga 18 November 2018, para diplomat Turki telah menemui sekira 600 menteri, 1444 anggota parlemen negara lain, pun 6190 pejabat senior seluruh dunia untuk meyakinkan mereka tentang bahaya apa yang mereka sebut sebagai "struktur FETO dan jaringan globalnya yang luas". Sumber yang sama juga mengungkapkan bahwa para diplomat Turki telah menghubungi kantor berita internasional sebanyak 2270 kali, menuliskan 448 artikel dan surat, dan mengorganisasi 236 pertemuan pers untuk isu yang sama (World Bulletin, 2016). Melalui upaya diplomatik di benua Afrika, Erdoğan berupaya menutup Sekolah-sekolah Gülen di 30 negara (Akca, 2019).

Upaya diplomatik ini tak sepenuhnya berhasil. Banyak pemerintah negara lain menganggap permintaan tersebut sebagai intervensi urusan domestik karena mereka tak memiliki landasan hukum untuk menutup Sekolah-sekolah Hizmet atau pengelolanya tak memiliki dakwaan kejahatan (Journalists and Writers Foundation, 2017). Meski demikian, The Maarif Foundation (TMF) lembaga semi-publik dan didanai pemerintah-mengklaim bahwa 80 organisasi FETO di luar negeri, termasuk sekolah-sekolah dan pusat latihan telah ditutup atau ditransfer ke Pemerintah Turki (World Bulletin, 2016). Upaya diplomatik Pemerintah Turki banyak terhambat isu kedaulatan dan intervensi urusan domestik negara lain.

Kendala dari jalur diplomatik dikompensasi Rezim Erdoğan dengan melakukan represi di luar batas negaranya. Sebuah laporan mengonfirmasi bahwa Badan Intelijen Nasional Turki (MIT) mendalangi pembunuhan lima orang-dua diantaranya guru Sekolah Gülen dan berpaspor Turki-dalam sebuah serangan bus di Mogadishu, Somalia, Maret 2016 (Journalists and Writers Foundation, 2017) (Turkish Minute, 2016). Selain melalui kekerasan fisik, intimidasi juga dalam bentuk deprivasi kewarganegaraan. Di beberapa negara, paspor para guru ditahan atau dibatalkan, membuat mereka nirkebangsaan (stateless). Keluarga mereka juga tak lepas dari persekusi dengan penolakan semena-mena para pegawai konsuler untuk pengajuan registrasi kelahiran anak-anak warga negara Turki yang dituduh terafiliasi FETO. Dari tiga dekrit yang dirilis untuk merespon kondisi darurat Turki, dua dekrit merupakan landasan hukum untuk merepresi mereka yang dituduh terafiliasi ke FETO. Satu dekrit menyasar guru-guru dan akademisi serta keluarga mereka yang mengajar di sekolah-sekolah privat di lebih dari 100 negara, sementara dekrit lain diperuntukkan untuk pencabutan kewarganegaraan bagi WN Turki yang tinggal di luar negeri dan tidak memenuhi panggilan pengadilan Turki dalam 90 hari (Journalists and Writers Foundation, 2017). 
Di Asia Tenggara, Malaysia dan Indonesia merupakan dua negara muslim yang memiliki lembaga afiliasi Gülen-termasuk sekolah-sekolahdan tempat aktivis Gerakan Gülen mengalami represi Pemerintah Turki. Di Malaysia, beberapa simpatisan Gülen diculik dan lainnya mendapatkan ancaman penculikan, deportasi, atau penahanan tanpa dakwaan. Dua kasus pertama muncul dari dua warga Turki teridentifikasi bernama Alettin Duman dan Tamer Tibik yang diculik di siang hari, dibawa ke hutan untuk disiksa dan dianiaya, untuk kemudian diserahkan ke Pemerintah Turki dan dipulangkan paksa ke Turki. Kasus ketiga terjadi pada Ismet Ozcelik yang ditahan paksa tanpa surat resmi namun kemudian dilepaskan setelah ada intervensi PBB ke Pemerintah Malaysia. Ia lantas ditangkap lagi pada bulan Mei. Kasus lainnya ialah penculikan seorang kepala sekolah, Turgay Karaman, di Kuala Lumpur, serta laporan kehilangan dari istri Ihsan Aslan, seorang pebisnis, sehari sebelumnya (Stockholm Center for Freedom, 2017).

Di Indonesia, belum ditemukan adanya represi dalam bentuk kekerasan fisik atau penculikan sejauh ini. Namun, beberapa kasus menunjukkan bahwa Pemerintah Turki mengintimidasi beberapa warga Turki-terutama para guru Sekolah Turki atau Sekolah Gülen-serta melakukan upaya pengambilalihan pengelolaan sekolah melalui The Maarif Foundation (TMF). Sembilan Sekolah Turki yang dituduh terkait Gülen di Indonesia tersebar di Aceh, Depok, Bandung, Tangerang Selatan, Yogyakarta, Semarang, Sragen, dan Banjarmansin. Kasus yang paling mencuat dalam masa turbulensi paskakudeta adalah penahanan paspor seorang guru Sekolah Kharisma Bangsa, Depok (Stockholm Center for Freedom, 2017). Sekolah Kharisma Bangsa juga bisa disebut Sekolah Turki atau Sekolah terkait Gülen karena yayasan sekolah ini bermitra dengan Pacific Countries Social and Economic Solidarity Association (PASIAD)_LSM Turki yang dituduh oleh Rezim Erdoğan berafiliasi ke Gerakan Gülen.

Kasus ini urgen untuk diangkat untuk menjelaskan bagaimana pemerintah otoriter Islamis Turki di masa Erdoğan menjalankan represi lintas batasnya ke negara demokratis berkekuatan menengah (middle power) seperti Indonesia serta menguji batasanbatasannya. Kedua negara ini memiliki hubungan baik yang bahkan bisa ditarik jauh sejarahnya sejak masa Khilafah Utsmaniyah dan kesultanan Islam di Nusantara. Namun, represi terhadap afilasi FETO di Indonesia mengharuskan Turki menghadapi risiko memburuknya hubungan antara dua negara muslim garda depan yang tergabung di banyak organisasi internasional yang sama ini. Pun berbeda dengan Malaysia yang melibatkan kekerasan fisik, dalam kasus Indonesia, Pemerintah Turki cenderung menempuh jalan nirkekerasan fisik dengan memaksimalkan peran perwakilan diplomatik dan lembaga semi-publik sebagai perpanjangan tangan.

\section{Represi Transnasional}

Kajian represi transansional dan globalisasi otoritarianisme yang mendiskusikan bagaimana negara otoriter menyasar warganya di luar negeri sebagai bidikan tindakan koersi bertumbuh dalam beberapa tahun terakhir (Moss, 2016; Chaudhary \& 
Moss, 2019; Cooley \& Heathershaw, 2017). Karya Moss (2016) melihat bagaimana represi dilakukan pada level mikro (invididu) di negara demokratis. Sedang karya Chaudhary \& Moss (2019) melihat bahwa kondisi geopolitik dan hubungan antar-negara-yakni kondisi ekonomi, politik, dan militer-yang asimetrik dan tidak baik antara negara besar dan menengah atau kecil, berdampak negatif pada diaspora yang mengalami represi. Dengan mengambil lokus di Asia Tengah, karya Cooley \& Heathershaw mengungkap bagaimana peran jaringan informal transnasional dalam melancarkan represi ekstrateritorial. Sejatinya pembidikan eksil politik dan oposisi sebagai target represi transnasional tidaklah sepenuhnya baru (Shain, 2005; Shain, 1990; Garvey, 1980). Misal lainnya, paska Revolusi 1917 aparat keamanan Soviet ditugaskan memburu eksil politik dan emigran, termasuk operasi yang menewaskan Leon Trotsky tahun 1940 di Mexico City atas suruhan Stalin (Soldatov \& Borogan, 2019) dan kerja sama antar-aparat keamanan enam negara Amerika Latin dalam Operasi Kondor untuk memburu para komunis dan lawan politik rezim-rezim otokrat (McSherry, 2005). Beberapa kasus kontemporer seperti pembunuhan jurnalis Arab Saudi, Jamal Kashoggi di Turki, pembunuhan dengan racun para imigran Rusia di Inggris, serta represi oposan politik oleh Iran dan Turki di beberapa negara menguatkan urgensi kajian ini. Meski demikian, dalam kajian keamanan internasional topik ini belum banyak dikaji (understudied) dan kurang berkembang dalam teorisasi (undertheorized).

Kajian kontemporer topik ini terwakili oleh karya penting Moss (2016) dan Cooley (2019). Moss mengkajinya melalui kasus aktivisme warga Libya dan Suriah di Amerika Serikat dan Inggris Raya. Menurutnya, represi transnasional cenderung beroperasi memanfaatkan kantor institusi perwakilan diplomatik mancanegara seperti kantor kedutaan, konsulat, dan misi. Institusi ini memiliki trifungsi, yakni sebagai: 1) penjaga gerbang, 2) stasiun satelit, dan 3) sponsor jejaring sosial bagi warga negaranya. Peran penjaga gerbang memfungsikan institusi tersebut sebagai pengatur akses ke negara asal dan melaluinya pejabat pemerintah bisa menghukum para pembangkang dengan mengasingkannya sebagai eksil politik atau memfasilitasi mereka pulang untuk direpresi di negara asal. Peran stasiun satelit mengandaikan institusi sebagai monitor pemantau beragam urusan dan kepentingan di mancanegara sehingga rezim diketahui melakukan pengawasan pada komunitas diaspora. Fungsi sponsor masyarakat sipil meniscayakan rezim menciptakan organisasi-organisasi yang mempromosikan kebijakan, ideologi pemerintah, serta loyalitas kepadanya. Temuan berharga Moss ialah tipologi represi transnasional yang terangkum dalam enam tindakan Pemerintah Libya dan Suriah kepada para aktivis oposisi di AS dan Inggris: padahan mematikan (lethal retribution), ancaman (threats), pengawasan (surveillance), pengasingan (exile), pembatalan beasiswa (withdrawing scholarships), dan hukuman proksi (proxy punishment) (Moss, 2016).

Sementara Coooley berkontribusi besar dalam menajamkan definisi, kriteria, serta bentuk-bentuk tindakan represi transnasional. Menurutnya, represi transnasional ialah "targeting of co-national political opponents, 
civil society advocates, non-pliant business community members and journalists who reside abroad by governments and their internal security and intelligence services" (pembidikan warga negara lawan/oposan politik, pembela masyarakat sipil, anggota komunitas bisnis yang membangkang, serta jurnalis yang tinggal di luar negeri yang dilakukan oleh pemerintah serta aparat keamanan dan intelijennya) (Cooley, 2019). Tiga kata kunci-eksil politik, diaspora, dan Teknologi Informasi (TI)_membingkai kriteria represi transnasional. Globalisasi sistem demokrasi liberal memunculkan arus balik gelombang otokrat baru yang memburu lawan politik, aktivis masyarakat sipil, hingga jurnalis, karena menganggapnya sebagai ancaman bagi keamanan domestik. Berkat globalisasi pula muncul komunitas diaspora para pencari perbaikan ekonomi yang punya potensi menjadi aktivis politik antirezim negara asal mereka karena mengalami radikalisasi. Sedangkan TI memiliki dua wajah, mampu mempromosikan kebebasan informasi namun juga membuat rezim otoriter bisa memonitor, menyigi, dan menginfiltrasi komunitas pembangkang di luar negaranya.

$$
\text { Cooley (2019) juga }
$$
mengidentifikasi tindakan-tindakan yang masuk dalam represi ekstrateritorial ialah, meski tidak terbatas pada: 1) aksi koersif pada eksil politik oleh aparat keamanan dan agen-agennya, termasuk di dalamnya pembunuhan dengan motif politik (assasination), penghilangan orang, penculikan paksa, dan pemulangan ke negara asal, 2) monitoring aktif, infiltrasi dan disrupsi komunitas eksil di mancanegara, 3) pelecehan dan intimidasi keluarga yang tinggal di dalam negeri dari eksil oposan politik untuk mencegahnya melakukan aktivisme di luar negeri, 4) pembatasan perjalanan ke luar negeri dan aktifitas profesional, 5) kerja sama dengan aparat keamanan negara asal dan negara tempat tinggal untuk menghambat eksil politik memproses/memotong prosedur legal yang memastikan kejelasan status pencari suaka politik. Kajian ini berupaya melihat dinamika represi ekstrateritorial antara dua negara berkekuatan menengah (middle power) yang relatif seimbang dalam kapabilitas ekonomi, politik, dan militer.

\section{Gülenis VS Erdoğanis}

Untuk lebih jernih menganalisis represi Rezim Erdoğan terhadap simpastisan Gülen di Indonesia, kita perlu melihat relasi Erdoğan-AKP dengan Gerakan Hizmet Gülen di Turki. Sejatinya sebelum dilabeli sebagai kelompok teroris dan pelaku Kudeta 15 Juli, Gerakan Gülen merupakan sekutu terpenting Rezim Erdoğan. Saat naik kekuasaan tahun 2002, Partai Keadilan dan Pembangunan (Adalet va Kalkimna Partisi/AKP) mendapat tentangan keras dari institusi-institusi negara, khususnya kelompok militer sebagai penjaga sekularisme/Kemalisme yang melihatnya memiliki tendensi Islamis dan gemar beretorika anti-sekuler. Untuk menandingi militer dan mengontrol lembaga-lembaga negara, Recep Tayyip Erdoğan-yang akhirnya menjadi Perdana Menteri-menunjuk para pengikut Gerakan Gülen untuk menduduki posisi-posisi kunci pemerintahan (Yavuz \& Koç, 2016). Dengan dukungan penuh Gerakan Gülen-faksi Islam terkuat saat ituAKP mampu mengelola pemerintahan sekaligus memonitor dari dekat kelompok militer-sekularis dengan bantuan para polisi. Kudeta 15 Juli juga 
menyingkap pengaruh Gerakan Gülen yang telah merasuk luas dan dalam ke militer, kekuatan politik Turki yang sebelumnya dikenal publik paling antiGülen.

Militer Turki dikenal luas sebagai kekuatan politik terkuat dan terdepan dalam membela sekularisme/Kemalisme. Militer yang selalu mendaku sebagai pendiri dan penjaga negara-bangsa sekuler Kemalis, tak membiarkan elemen gerakan agama apapun menyusup di sistemnya. Secara reguler, militer selalu melakukan pembersihan personelnya yang terindikasi memiliki afiliasi etnis, keagamaan, atau kecenderungan paham sosialis. Menariknya, Gerakan Gülen secara sistematis malah memanfaatkan pembersihan di tubuh militer ini untuk membangun jaringan klandestin dan terkontrol ketat untuk merekrut dan mengembangkan pengikut sembari menggusur mereka yang anti-Gülen (Yavuz \& Koç, 2016). Kesamaan pandang dalam melihat militer sebagai musuh, membuat Erdoğan menjadikan Gerakan Gülen sebagai sekutu strategis dalam menggerus pengaruh kekuatan militer.

Erdoğan banyak menunjuk birokrat pro-Gülen memimpin posisi penting pemerintahan. Mereka mengisi pos-pos krusial, termasuk kepolisian, kehakiman, dan kementerian pendidikan dan kesehatan. Begitu mendalamnya penguasaan pro-Gülen di birokrasi, mereka sering disebut sebagai "deep state" (Jenkins, 2009) atau "parallel state" (Pujayanti, 2009) dan membantu para aktivis AKP untuk mentrasformasi institusi-institusi negara. Beraliansi dengan Gerakan Gülen merupakan strategi paling efektif yang dilakukan
Erdoğan karena gerakan ini memiliki banyak simpatisan birokrat terlatih, terdidik, dan kompeten. Berkat jaringan globalnya, Gerakan Gülen membantu para pengurus AKP membangun jaringan internasional yang berfungsi sebagai "kedutaan paralel" bagi pemerintah (Yavuz \& Koç, 2016).

Gerakan Gülen yang mulanya merupakan entitas pendidikan yang berfokus pada pembentukan kesalehan diri dan masyarakat, bertransformasi menjadi organisasi keagamaan-politik rahasia pro-kekerasan diikat dengan ideide keagamaan dan kepentingan material (Yavuz \& Koç, 2016). Gerakan ini menyasar kendali kepemerintahan dan mengincar peluang-peluang kekuasaan. Karena penolakan dan persekusi, gerakan ini membangun tradisi kerahasiaan untuk menaklukkan institusi keamanan, yakni kepolisian, militer, dan intelijen. Untuk itu mereka mempraktikkan taqiyyah: menyembunyikan maksud dan tujuan untuk mengontrol posisi kekuasaan kunci.

Ada kesenjangan persepsi publik Turki tentang strategi klandestin Gerakan Gülen. Warga Turki menduga bahwa pergeseran Gülenis menempuh strategi kerahasiaan dan kekerasan karena hubungannya dengan Central of Intelligence Agency (CIA) AS. AKP memanfaatkan prasangka konspiratif publik ini untuk menyelubungi kesalahannya membiarkan Gerakan Hizmet Gülen menjalani proses transformasi. Namun, sejatinya kesuksesan Hizmet dalam mengakumulasi kekuasaan dan mendominasi akses sumber daya nasional dengan bantuan AKP di beberapa dasawarsa terakhir lahir dari 
empat faktor lain; kegagalan institusiintitusi negara dan menganganya kesenjangan sosiologis di dalamnya, polarisasi sistem partai, kepemimpinan yang lemah di kementerian, dan secara khusus adanya manipulasi lembaga kepolisian dan peradilan. Kondisi politik Turki yang dipenuhi korupsi, nepotisme, serta pemahaman Islam yang secara vulgar ditampilkan dalam kekuasaan menjadi prakondisi untuk ini. Puncaknya, sejak 2007 Gerakan Gülen menjadi mitra Rezim AKP dalam mengontrol lembaga kementerian dalam negeri, pendidikan, kehakiman, serta kementerian luar negeri, pun para pegawai di dalam tiap kementerian tersebut (Yavuz \& Koç, 2016).

Titik balik bagi Gerakan Gülen untuk menjadi gerakan bayangan adalah Kudeta Turki 1997. Pada 28 Oktober 1997 militer Turki yang mendominasi National Security Council (NSC) memobilisasi ornop sekularis, kehakiman, dan pebisnis besar untuk memaksa PM Necmettin Erbakan-PM Islamis pertama dan pemimpin Parta Refah-turun dari jabatannya. Militer menuduh Erbakan melakukan Islamisasi pemerintahan dan melanggar konstitusi yang memisahkan agama dan negara. Segera setelah itu militer mengajukan aturan-aturan membatasi seluruh aktifitas Islamisasi negara dan masyarakat. Untuk menghindari jadi target buruan NSC, Gerakan Gülen memutuskan menjadi gerakan klandestin dan makin menutup diri setelah pengadilan para pemimpinnya atas tuduhan melakukan kerja-kerja intelijen. Ketika konfigurasi politik berubah tahun 2002 saat AKP naik kekuasaan, Gerakan Gülen membuka diri untuk menjadi mitra partai penguasa baru sekaligus menaikkan citranya sebagai kelompok Islam moderat. Tugas yang dibebankan AKP ke Gülenis jelas: membantu menjauhkan Turki dari tradisi kudeta militer Kemalis terhadap pemerintah yang terpilih secara demokratis.

Sampai kasus korupsi AKP mencuat tahun 2013, Gerakan Gülen secara sistematis melemahkan militer lewat jejaringnya di kepolisian, kehakiman, dan berbagai lembaga negara. Kasus-kasus pengadilan Ergenekon, Sledgehammer, dan skandal spionase Izmir, difabrikasi atas dukungan negara melalui gurita kekuasaan Gülenis yang tersebar di institusi pengadilan dan kepolisian. Pengadilan ini berhasil mendakwa dan memenjarakan para petinggi militer, jurnalis, dan politisi, atas dakwaan membangun organisasi klandestin untuk menjatuhkan pemerintahan sipil melalui serangkaian upaya kudeta, pembunuhan, dan aktifitas politik subversif.

Hubungan simbiosis-mutualistik AKP-Gülen pada akhirnya memburuk drastis sebagai dampak konflik berkepanjangan keduanya karena perebutan kontrol posisi kunci pemerintahan dan alokasi sumber daya. Dimulai dari hancurnya kepercayaan Erdoğan, mewujud pada konflik terbuka, dan dipuncaki dengan upaya Kudeta 15 Juli faksi Gülenis terhadap Pemerintahan Erdoğan. Benih perpecahan sebenarnya telah ada sejak dari mula: perbedaan ideologi yang dalam. Gülenis pro-Barat, percaya pada edukasi elit dan kepemimpinan, skeptis pada kekuatan massa, serta lebih meyakini otoritas kepemimpinan religiopolitik seperti ketaatan mereka pada Fethullah Gülen. Pandangan ini berbeda dengan petinggi AKP-Erdoğanis yang 
lebih mengandalkan kepemimpinan dari massa politik dan demokrasi. Perbedaan keduanya juga terletak pada cara pandang kebijakan luar negeri Turki di Timur Tengah. Gülenis berupaya menarik simpati kelompok Neokonsevatif AS dan membangun aliansi dengan Washington melalui posisinya yang tidak kritis soal Israel dan anti-Iran sembari meninggikan kebijakan pasar bebas. Sebaliknya, AKP pro-Palestina, bersetuju untuk melakukan rekonsiliasi dengan Iran, menekankan pentingnya membangun ikatan historis dengan Timur Tengah, sembari mempromosikan gerakan demokratis berbasis massa muslim.

Memburuknya hubungan keduanya ditandai dengan saling balas serangan politik yang memanfaatkan organ-organ negara. Konflik dimulai dengan skandal penyadapan kantor dan rumah Erdoğan tahun 2011 dengan melibatkan para polisi kepercayaantermasuk kepala pengawal pribadinyayang meletakkan alat sadap di kantornya. Erdoğan tidak hanya hilang kepercayaan pada pengikut Gülen, ia membalas penyadapan itu dengan menutup kelaskelas persiapan masuk kampus swasta milik Gerakan Gülen yang menjadi sumber pendanaan dan pintu utama rekrutmen gerakan pada 2012. Sengketa berlanjut secara terbuka dengan para Gülenis melucuti orang-orang terdekat dan kepercayaan Erdoğan. Jaksa Istanbul Sadrettin Sarikaya-yang menurut sumber AKP adalah pengikut Gülen-memanggil Direktur Jenderal Badan Intelijen Nasional Turki (MIT), Hakan Fidan-orang dekat kepercayaan Erdoğan-dan pendahulunya, Emre Taner, untuk diinterogasi soal perekrutan warga Kurdi dari Kurdistan Communities Union (KCK) yang telah melakukan kekerasan pada aparat dan warga Turki. Drama politik ini berujung dengan Rezim AKP mencopot Jaksa Sadrettin Sarikaya dan amandemen hukum untuk melindungi petinggi MIT dari dakwaan politik. Untuk melumpuhkan sumber asupan finansial dan sumber daya manusia, pada November 2013 Erdoğan bermanuver menutup "sekolah-sekolah persiapan" Gülen.

Akhir 2013 menandai ketegangan eskalatif menjadi "perang puputan” Gülenis versus Erdoğanis yang makin tak terkendali dan terbuka serta berpuncak pada Kudeta 15 Juli 2016. Pendukung Gülen menggaungkan kasus korupsi dan nepotisme petinggi AKP Desember 2013 sebagai awal huruhara politik Turki. Polisi Istanbul Departemen Finansial dan Unit AntiKorupsi, pada 17 Desember 2013, menahan 47 tersangka koruptor, termasuk tiga anak menteri; Baris Guler (anak Menteri Dalam Negeri), Kaan Caglayan (anak Menteri Ekonomi), dan Ogus Bayraktar (anak Menteri Lingkungan dan Pembangunan Kota). Termasuk mereka yang ditahan adalah para pejabat tinggi pemerintahan pusat dan daerah serta pebisnis dalam negeri dan luar negeri. Pejabat polisi dan pengadilan yang terkoneksi ke Gerakan Gülen memainkan peran besar dalam pengungkapan korupsi ini. Erdoğan membantah semua tuduhan korupsi dan mulai membangun narasi kudeta untuk memukul balik para jaksa, polisi, dan hakim simpatisan Gülen, dengan menuduh mereka melakukan "kudeta yudisial". Kondisi diperburuk dengan bocornya percakapan antara Erdoğan, anaknya, dan para menteri. Erdoğan merespon cepat dengan mengumpulkan semua sumber daya yang dimilikinya dan 
memburu para penuduh, serta membidik secara khusus Gerakan Gülen sebagai aktor utama yang menjadi kepanjangan tangan kepentingan asing. Ia mem-framing skandal korupsi ini sebagai "operasi global" yang didalangi oleh Gerakan Gülen dan sekutu asing untuk menjatuhkan pemerintahan yang sah. Sengketa keras bekas sekutu dekat itu meninggalkan kesumat dan meracuni kehidupan politik Turki secara mendalam yang sepertinya akan bertahan lama. Muncul pembelahan biner sebelum Kudeta 15 Juli: semua pengkritik pemerintah akan otomatis dilabeli "Gülenis", dan sebaliknya, semua pengkritik Gerakan Gülen akan serta-merta distigma "Erdoğanis".

\section{Puncak semua pertengkaran} tajam AKP-Gerakan Gülen adalah Kudeta 15 Juli yang gagal dan mengubah para simpatisan Gülen-termasuk loyalisnya di tubuh militer-menjadi pesakitan politik. Dua pekan menjelang kudeta, koran-koran Turki dipenuhi berita kemungkinan adanya pembersihan besar-besaran dan pencopotan tentara loyalis Gülen. Setelah menyadari waktunya hampir habis, para perencana kudeta segera memutuskan untuk melancarkan kudeta ala Kamikaze (Ozkan, 2016; Reynolds, 2016). Erdoğan dan Rezim AKP melakukan stigmatisasi Gerakan Gülen sebagai ancaman keamanan nasional dan internasional, mengerahkan semua alat negara untuk mendelegitimasi gerakan ini, dan melucutinya dari institusi politik dan pemerintahan Turki. Koneksi, afiliasi, atau simpati dengan Gerakan Gülen sudah cukup menjadi alasan untuk Pemerintah Turki melakukan intimidasi, penangkapan dan pembersihan-lebih atas dasar identifikasi keterkaitannya dengan gerakan ini daripada dikarenakan tindakan yang dilakukan-dan memburu mereka hingga ke luar negeri.

\section{Tekanan Diplomatik Kedutaan Turki dan Sekolah Gülen Indonesia}

Upaya represi Rezim Erdoğan kepada aktivis Gerakan Gülen juga menyasar mereka yang ada di Indonesia. Masih di bulan yang sama dengan upaya kudeta, 28 Juli 2016, Kedutaan Turki di Jakarta merilis pernyataan pers yang menyatakan akibat ancaman keamanan serius dan multidimensional, Pemerintah Turki mendeklarasikan keadaan darurat dan perlu melindungi demokrasi dengan mengambil langkahlangkah yang diperlukan untuk menghukum pelaku kudeta yakni "kelompok teroris FETO dan pemimpinnya, Fethullah Gülen, yang tinggal di AS". Rilis resmi Kedutaan juga menyatakan bahwa di Indonesia "ada beberapa sekolah yang terhubung dengan kelompok teroris dan payung organisasinya, PASIAD (Pasifik UTkeleri ile Sosyal ve Tketisadi Dayamisma Derneğ telah ditutup per 15 November 2015" serta meminta bantuan Pemerintah Indonesia untuk menutup sekolahsekolah tersebut. Secara eksplisit juga disebutkan sembilan sekolah yang tertaut dengan kelompok teroris FETO; 1) Sekolah Bilingual Pribadi Depok, 2) Sekolah Bilingual Pribadi, Bandung, 3) Sekolah Kharisma Bangsa, Tangerang Selatan, 4) Sekolah Bilingual Semesta, Semarang, 5) Sekolah Kesatuan Bangsa, Yogyakarta, 6) Sekolah Bilingual, Sragen, 7) Sekolah Fatih (untuk Putra), Banda Aceh, 8) Sekolah Teuku Nyak Arif Fatih (untuk Putri), Banda Aceh, 9) Sekolah Banua Bilingual, Kalimantan 
Selatan (Turkish Embassy in Jakarta, 2016)

Permintaan Kedutaan Turki di Jakarta untuk menutup sekolah-sekolah Turki Gülen tak mendapatan sambutan baik dari Pemerintah Indonesia. Menteri Pendidikan dan Kebudayaan (Mendikbud) Muhadjir Effendy-yang baru saja naik menggantikan Anies Baswedan karena reshuffle beberapa hari sebelumnya-menyatakan

(29/07/2016) bahwa sekolah-sekolah Turki tidak ditutup karena kontrak bantuan menajemen PASIAD telah selesai sejak 2015 sembari memastikan bahwa kurikulum yang dipakai disana adalah kurikulum nasional dengan penambahan penggunaan dwi-bahasa Indonesia dan Turki. Ia menyatakan, "Siswanya tetap sekolah. Siswanya tidak kenapa-kenapa. Ya nggak (ditutup), masa mengorbankan siswa kita hanya karena teror (di Turki)". Sekretaris Direktorat Jenderal Pendidikan Dasar dan Menengah Kemendikbud, Thamrin Kasman, menyatakan hal senada, "Sejak PASIAD ditutup oleh Kemlu pada November 2015, semua sekolah tersebut sudah tidak ada afiliasi dengan PASIAD” (Detiknews, 2016b).

Tekanan diplomatik Turki melalui kedutaannya mendapat reaksi negatif juga dari para pejabat negara dan masyarakat. Sekretaris Kabinet mengaitkan permintaan Turki tersebut dengan isu intervensi urusan dalam negeri dan kedaulatan Indonesia, "Indonesia merupakan negara demokratis dan akan selalu memprioritaskan politik bebas-aktif. Urusan dalam negeri Indonesia tetap merupakan tanggung jawab Indonesia" (The National, 2016). Kementerian Luar Negeri (Kemenlu) juga menyampaikan sikap yang sama namun dengan pernyataan yang lebih diplomatis dengan menyatakan bahwa Indonesia menghindari untuk terlibat mencampuri urusan dalam negeri negara lain. Juru Bicara Kemneterian Luar Negeri (Kemenlu), Arrmanatha Nasir, menekankan, "Kami mengetahui hal ini tadi pagi. Saya lihat dari web Kedubes Turki. Pertama yang saya ingin sampaikan bahwa pemerintah Indonesia tidak pernah terlibat atau mengurusi permasalahan dalam negeri negara lain. Kami tidak ikut campur" (Kompas.com, 2016; Republika.co.id, 2016).

Penolakan juga muncul dari sekolah-sekolah tertuduh yang menganggap hubungan dengan PASIAD hanyalah informal. Pihak Kepala Sekolah Kharisma Bangsa, misalnya, menekankan bahwa sekolahnya kini tidak memiliki hubungan dengan lembaga apapun di Turki. Menurutnya, kontrak dengan PASIAD telah berakhir dua tahun sebelumnya (2014) dan kerja sama dengan lembaga Turki itu memiliki payung hukum dari Kemendikbud saat masih di bawah Mendikbud Anies Baswedan. Sekolah Kharisma Bangsa memiliki 80 guru dengan 15 diantaranya adalah guru berkebangsaan Turki (Detiknews, 2016). Menurutnya lagi, sekolahnya memang masih mempekerjakan pengajar Turki tapi kini secara individu dan tidak lagi atas kerja sama dengan PASIAD (TangerangOnline.id, 2016) Hatta para murid yang belajar di sekolah itu merasa tertekan dan resisten pada upaya Turki menutup sekolah mereka (BBC News Indonesia, 2016).

Meski pihak pengelola Sekolah Turki menolak dikaitkan dengan 
PASIAD, namun kehadirannya di Indonesia memang tak bisa dipungkiri terkait erat dengan Gerakan Gülen di Indonesia yang masuk sejak tahun 1993. Gerakan Gülen masuk ke Indonesia dibawa oleh tiga pelajar Turki; Hakan Islamoglu, Kerim Tursun, dan Galip Kayar. Keputusan ketiganya untuk belajar di Indonesia bisa dikatakan sangat aneh mengingat dari ketiganya tidak ada satupun yang bisa berbicara dengan Bahasa Indonesia. Lewat koneksi Haji Alwi-orang Indonesia yang pernah belajar di Turki-Hakan Islamoglu tidak hanya bisa berkuliah di Universitas Indonesia, tapi juga membangun kedekatan personal dengan beberapa birokrat, politikus, dan akademia Indonesia yang membantunya mengenalkan Gerakan Gülen dan mendirikan sekolah serta yayasan. Lewat wawancara dengan Hakan Islamoglu, pendiri PASIAD Indonesia pertama, Osman mencatat bahwa Burhanuddin Abdullah-Direktur Bank Indonesia saat itu-membantu Islamoglu mendirikan Sekolah Pribadi, Depok, sementara Dr Aip Syarifuddin (politikus) dan Firman Kartiman membantunya mendirikan Yayasan Yenbu yang menaungi Sekolah Pribadi Depok. Setelah berpindah kuliah di UGM, ia membangun kedekatan dengan Prof. Dr. Siti Chamamah SoeratnoGuru Besar UGM dan Tokoh Aisyiyah-yang tertarik ingin mendirikan sekolah sejenis. Ketertarikan ini mendorong berdirinya Yayasan AlFirdaus Semarang yang berkat bantuan PASIAD Indonesia akhirnya yayasan ini mendirikan SMP-SMA Semesta (Osman, 2008). Sesudahnya, sekolahsekolah serupa didirikan di Bandung (2002), Banda Aceh (2005), Tangerang (2007), Sragen (2008), Yogyakarta (2011), Banjarmasin (2012). Dari sembilan sekolah, tujuh sekolah dikelola yayasan swasta, sementara dua sekolah lainnya merupakan kerja sama kemitraan Pemda Sragen dan di Banjarmasin dengan PASIAD.

\section{Proksi Denasionalisasi WN Turki}

Kegagalan Kedutaan Turki di Jakarta untuk menekan Pemerintah RI melalui jalur diplomatik dikompensasi dengan merepresi warga negaranya di Indonesia secara langsung. Paskakudeta, Erdoğan telah membekukan 50.000 paspor WN Turki dan Kedutaan Turki di sejumlah negara tidak memberikan layanan administrasi kepada terhadap anggota Hizmet, termasuk yang ada di Indonesia. Penyitaan paspor ini hanya bisa diselesaikan setelah korban melapor ke Interpol (Komnasham.go.id, 2016). Komnas HAM juga menerima pengaduan dari seorang WN Turki yang mengkhawatirkan keselamatan dirinya. Meski belum ada laporan tentang kekerasan fisik terhadap WN Turki di Indonesia, namun bentuk-bentuk represi seperti pengawasan aktif, penahanan paspor, intimidasi terhadap keluarga, serta pembatasan perjalanan dan aktifitas profesional, bisa ditemukan disini.

Pembekuan paspor oleh Kedutaan Turki dialami oleh guru sekolah Turki. Kedutaan Turki dan Konsulat secara semena-mena menolak memberikan layanan konsuler pada Yusuf Tanriverdi-guru Biologi Sekolah Kharisma Bangsa, Tangerang Selatan-yang dituduh berafiliasi ke Gerakan Gülen. Saat ingin memperpanjang visa, paspornya ditahan dan pihak kedutaan menyampaikan bahwa hanya akan mengembalikannya setelah pemohon bersedia diinterogasi 
serta menawarkan surat keterangan jalan yang memunculkan kekhawatiran akan penahanannya saat tiba di Turki. Sayangnya, setelah berbulan-bulan paspornya tak kunjung diberikan hingga visanya kadaluwarsa. Tanpa dokumen identitas apapun, ia lantas menjadi warga ilegal dan tanpa kewarganegaraan di Indonesia. Ia memulangkan istri dan anaknya ke Turki dan mengajukan status pengungsi ke kantor perwkilan PBB di Indonesia. Berkat aplikasi pengungsi inilah ia bisa tinggal di Indonesia. Stockholm Center for Freedom mencatat ada sekitar 15 WN Turki yang takut kembali ke Turki dan mengajukan aplikasi yang sama ke kantor PBB agar bisa tinggal secara legal seperti Tanriverdi (Komnasham.go.id, 2016; Stockholm Center for Freedom, 2017)

Penyitaan paspor oleh Kedutaan Turki merupakan represi administratif yang menjadikan WN Turki nirkewarganegaraan dan ilegal. Kondisi ini juga terjadi pada Mustafa Kenel, pebisinis Turki dan anggota TurkishIndonesia Trade Association (TITA) yang juga merupakan simpatisan Hizmet. Penahanan paspor membuatnya tertangkap saat razia oleh petugas imigrasi Indonesia beserta dua WN Turki lain. Dua WN Turki akhirnya dilepas karena memiliki dokumen lengkap, sementara Kenel akhirnya dideportasi pada 16 Desember 2017 (Jawa Pos, 2017). LSM internasional, Journalists and Writers Foundation (JWF) menyatakan bahwa ia dideportasi karena permintaan Pemerintah Turki kepada Pemerintah Indonesia untuk menyerahkan simpatisan Gülen (Journalists and Writers Foundation, 2018). Adanya daftar simpatisan Gülen membuktikan juga bahwa Turki melakukan pengawasan aktif pada diaspora Turki. Mekanisme ini bekerja juga pada diaspora yang aktif melakukan perjalanan. Enes Kanter, seorang atlit profesional dan bintang basket NBA AS yang juga simpatisan Gülen, mengaku pernah akan diculik saat berada di Indonesia untuk suatu acara amal coaching clinic basket di Jakarta. Dalam waktu kurang dari 24 jam ia kabur ke Singapura karena mengetahui bahwa Pemerintah Turki meminta Pemerintah Indonesia untuk menangkapnya atas tuduhan orang yang berbahaya. Ia, yang mengkritik keras Erdoğan karena menghukum ayahnya 15 tahun penjara karena terkait Gülen, juga sempat tertahan di Rumania karena Pemerintah Turki mencabut paspornya dan memaksa AS turun tangan membawanya pulang ke AS (Liputan6.com, 2018).

Tindakan adminsitrasi agresif seperti penyitaan paspor WN Turki oleh Kedutaan Turki tak ubahnya upaya denasionalisasi proksi. Terma "denasionalisasi proksi" (proxy denationalization) merupakan upaya pencabutan kewarganegaraan oleh institusi perwakilan suatu negara di luar negeri atas nama otoritas eksekutif dan atau yudikatif di negara asalnya. Dari kasus pencabutan kewarganegaran AS keturunan Yaman, Kassem memperkenalkan istilah "denaturalisasi proksi" (proxy denaturalization) (Kassem, 2014). Sementara itu denasionalisasidalam konteks ini bermakna pencabutan kebangsaan atau kewarganegaraanmerupakan hukuman bagi perilaku tertentu (seperti ketidakloyalan atau melakukan kejahatan serius) untuk melindungi kepentingan vital negara. Ia menjadi isu kontoversial di negara liberal saat ini terutama sejak mencuatnya kasus-kasus terorisme. Meski sering 
dipertukarkan, Gibney membedakan antara "kebangsaan" (nationality) dan "kewarganegaraan" (citizenship). Jika yang pertama memiliki dimensi eksternalitas_yakni keanggotaan pada suatu negara vis a vis negara lain, yang kedua mengandung dimensi internalitas-yang melibatkan hubungan domestik antara individu dengan negara dan dengan sesama warga negara (Gibney, 2013). Sebagai bentuk intimidasi pada keluarga Gülenis, Pemerintah Turki juga tidak memberikan layanan pencatatan surat keterangan lahir bagi anak-anak mereka yang lahir di lur Turki. Penolakan layanan konsuler sepertik penolakan penerbitan surat keterangan lahir bagi anak WN Turki juga terjadi di Indonesia. Tercatat hingga April 2018 ada tujuh kasus bayi Turki yang lahir di Indonesia tanpa keterangan identitas dari Kedutaan Turki (Journalists and Writers Foundation, 2018). Tindakan denasionalisasi proksi terhadap WN Turki juga sekaligus menjadikan mereka sebagai eksil politik.

\section{Pembersihan Sekolah-sekolah Turki terkait Gülen}

Represi Rezim Erdoğan berupaya menembus hingga ke institusi sekolah di Indonesia. Pemerintah Turki, investigator independen, atau laporan media Turki seperti Hurriyet menemukan bahwa institusi afiliasi Gerakan Gülen di luar negeri merupakan salah satu pemasok aliran dana vital bagi organisasi bayangan ini. Melalui sekolah-sekolah, rumah sakit, yayasan, dan lembaga-lembaga lain, FETO mendapatkan pendanaan untuk membiayai tindakan-tindakan ilegal seperti penyuapan petugas (agar menulis laporan yang baik untuk lembaga afiliasi Hizmet), mendukung lembaga-lembaga sejenis di negara lain, hingga misinformasi dan upaya pemerasan melalui kantor berita. Investigasi yang mengungkap ini pernah dilakukan oleh Mark Hall dan David Hearst yang menyingkap bagaimana simpatisan FETO tak hanya menyalurkan uang dari luar negeri untuk mendanai upaya kudeta atau upaya jahat lain untuk mendestabilkan Turki, tapi juga melanggar hukum dan aturan di negara mereka beroperasi. Dari penyalahgunaan dana seperti inilah, Edward Garner-seorang anggota parlemen Inggris dari Partai Konservatif-menerima dana sekira USD 150 ribu $(\operatorname{Rp} 2,5 \mathrm{M})$ untuk menulis laporan negatif tentang Turki. Bukti ini didapat dari laporan resmi di AS yang digunakan untuk menangkal propaganda hitam untuk menjelekkan Turki di Inggris dan Pakistan (Nugraha, 2016). Bukti-bukti ini dijadikan landasan Rezim Erdoğan membidik sekolahsekolah Turki termasuk di Indonesia.

Tuduhan bahwa institusi Gülen di luar negeri melakukan penyalahgunaan, dalam konteks ini penyalahgunaan wewenang, setidaknya terkonfimasi di Indonesia. Wakil Kepala Humas Sragen Bilingual Boarding School (SBBS), Ari Mayang, menyatakan bahwa PASIAD hadir di Indonesia dengan menawarkan proposal untuk mendirikan sekolah dan bertujuan membantu pelajar Indonesia untuk melanjutkan studi ke Turki. Tujuan awal PASIAD ialah menjadi mitra dalam pengelolaan sekolah. Tujuan itulah yang diketahui dari proposal kerja sama yang diajukan oleh PASIAD ke Kemendikbud. Namun, hasil evaluasi Kemendikbud pada tahun 2015 menemukan bahwa PASIAD tidak hanya membantu dalam manajemen sekolah, tapi juga membawa dan 
mempekerjakan guru-guru Turki yang terafiliasi ke Gerakan Gülen. Ari Mayang mengonfirmasi adanya penyalahgunaan wewenang, "Sebab, PASIAD yang semula mengusung program bantuan pendidikan itu kenyataannya justru bekerja. Jadi guruguru asing (dari PASIAD) itu kami yang menggaji" (Tempo.co, 2016). Sebuah penelitian tahun 2011 menemukan bahwa di tahun 2010 dari 20 guru yang bekerja di SSBS Sragen-sekolah negeri yang bermitra dengan PASIAD sejak pendiriannya tahun 2008- enam guru merupakan guru Turki dari PASIAD, dan delapan dari 28 pegawai administrasi merupakan orang PASIAD (Rohmawan, 2011). Salah satu guru SSBS, Yusuf Tanverdi, merupakan guru Biologi yang pada tahun 2016 paskakudeta ditahan paspornya oleh Kedutaan Turki dengan status terakhir guru di Sekolah Kharisma Bangsa.

Pada akhirnya Pemerintah Turki sadar bahwa permintaan mereka pada Pemerintah RI untuk menutup SekolahSekolah Gülen di Indonesia direspon dengan dingin. Mereka lantas menempuh cara alternatif dengan berupaya mengontrol Sekolah-sekolah Turki, memecat staf sekolah dan menggantikannya dengan orang-orang non-Gülenis. Untuk itu mereka memanfaatkan lembaga semi-publik, The Maarif Foundation (TMF), demi menjalankan misi pembersihan ini. Secara global, Ketua TMF, Birol Akgun, mengklaim telah mengakusisi 191 sekolah dari Gerakan Gülen di 21 negara. Menurutnya, 70\% dari sekolahsekolah Gülen di negara non-Barat telah berhasil dikontrol. Beragam cara telah ditempuh TMF. Salah satunya: jika sekolah tak berhasil ditutup, maka mereka menyebarkan kampanye hitam pada lulusan sekolah Gülen bahwa mereka tidak bisa melanjutkan studi ke Turki (Stockholm Center for Freedom, 2019). Namun sejatinya upaya Turki menutup sekolah-sekolah ini tak berjalan sukses. Di Eurasia, hingga tahun 2016 hanya Azerbaijan-sekutu regional Turki terdekat-yang menyambut upaya represi lintas batas terhadap sekolah-sekolah Gerakan Gülen ini (Eurasia, 2016). Di Afrika, hanya negara-negara Sub-Sahara yang merespon permintaan Turki untuk menutup sekolah atau mentransfer pengelolaannya ke TMF. Kebijakan penutupan atau pengambilalihan sekolah-sekolah Gülen efektif terjadi di Somalia, Guinea, Nigeria, Senegal, Mali, Sudan, Burundi, dan Benin. Angey melihat bahwa keberhasilan di Afrika Sub-Sahara ini karena Turki melancarkan manuver diplomatik spesifik dan ketimpangan kapabilitas ekonomi antara Turki dan negara-negara Afrika. Somalia dan Nigeria merupakan negara penerima bantuan luar negeri Turki dalam jumlah besar. Hubungan disimetris dengan negara-negara Afrika memudahkan Turki mentransfer represi terhadap Gerakan Gülen disana (Angey, 2018).

Di Indonesia, Pemerintah Turki akhirnya melunak dengan tidak memaksakan penutupan atau pengambilalihan sembilan sekolahsekolah Gülen, namun berganti haluan melakukan pembersihan guru-guru di dalamnya. Duta Besar Turki, Mehmet Kadri Sander Gurbuz, menyatakan lewat kantor berita pemerintah Anadolu Agency pada 2018 bahwa jika Pemerintah RI dan pihak sekolah membutuhkan, Turki siap memberikan bantuan dalam bentuk pengiriman guruguru baru dan pendanaan. Di 
kesempatan yang sama, Dubes Gubruz juga mengklaim TMF telah mengambil alih sekolah terkait FETO di 10 negara dengan empat berikutnya akan menyusul (Anadolu Agency, 2018). Dalam tahun 2018-2019, TMF mengubah strategi dengan lebih banyak merangkul organisasi moderat yang menaungi sekolah-sekolah swasta seperti NU dan Muhammadiyah dan berkerja sama dengan sekolah-sekolah baru seperti Sekolah Syifa Budi (Anadolu Agency, 2019; Kemlu.go.id, 2019; TRT Melayu, 2018)

Sikap Indonesia yang enggan mengakomodasi permintaan Turki untuk menutup atau mengambil alih sekolah terkait Gülen lahir dari keberimbangan kekuatan ekonomi dan politik yang menghasilkan pola hubungan setara. Selain karena kontrak PASIAD yang berakhir tahun 2015 dan potensi merugikan para murid, argumen kedaulatan termasuk yang kuat menghalangi Indonesia meluluskan permintaan Turki. Banyak pihaktermasuk Mendikbud dan para jubir pemerintah-berargumen bahwa menyetujui permintaan Turki untuk melakukan investigasi pada sekolahsekolah terkait Gülen tak ubahnya membiarkan negara asing mendikte Indonesia. Jika demikian, maka Indonesia akan menjadikan dirinya mudah didikte seperti kasus-kasus sebelumnya-saat AS, Australia, dan China, melacak, memburu, dan menangkap terduga pelaku kriminal dan teror (Nugraha, 2016).

\section{Kesimpulan}

Usai Kudeta 15 Juli 2016 yang gagal, Ankara menghukum Gerakan Gülen dan para pengikutnya-yang dinyatakan sebagai pelaku kudeta—dengan melabeli mereka sebagai organisasi teroris FETO serta memburu dan merepresinya hingga ke luar negeri termasuk Indonesia. Turki secara agresif melakukan tiga level pendekatan untuk ini; makro, meso, dan mikro. Di level makro mereka menjalankan kampanye diplomatik memanfaatkan jalur hubungan antarpemerintah ( $G$ to $G$ ) dengan mendiskreditkan Gerakan Gülen sebagai kelompok teroris FETO dan meminta Pemerintah RI menutup sekolah-sekolah terkait Gülen. Di level meso, mereka berupaya mengambil kontrol sekolah-sekolah Gülen dan mentransfernya di bawah kendali The Maarif Foundation (TMF). Sementara di level mikro, mereka membidik individu, yakni guru-guru sekolah terkait Gülen melalui upaya denasionalisasi proksi, pengawasan aktif, dan intimidasi keluarga simpatisan Gülen. Studi ini mengisi kesenjangan kajian tentang keterbatasan praktik-praktik represi transnasional di negara yang demokratis dan setara secara ekonomi-politik dengan negara otoriter pelaku represi. Represi Rezim Erdoğan di Indonesia terbukti hanya efektif dijalankan pada level mikro, yakni dengan merepresi warga negara Turki pengikut Gülen melalui pencabutan kewarganegaraan, pengawasan aktif diaspora Turki, serta penolakan untuk memberikan layanan konsuler untuk mengintimidasi keluarga Gülenis. Kegagalan kampanye diplomatik menjadikan upaya transfer konflik nasional Turki menjadi konflik internasional menemui jalan buntu dan terbentur isu kedaulatan Indonesia. Pemerintah Turki pun melunak dan mengubah tuntutan dan pendekatannya: dari meminta Pemerintah RI untuk menutup sekolah ke upaya pembersihan sekolah dan menjalin kemitraan baru 
dengan organisasi-organisasi nonpemerintah di Indonesia.

\section{DAFTAR PUSTAKA}

Akca, A. (2019). Neo-Ottomanism: Turkey Foreign Policy Approach to Africa. New Perspectives in Foreign Policy, (17), 03-08. Retrieved from https://www.csis.org/analysis/ne w-perspectives-foreign-policyissue-17

Anadolu Agency. (2016). FETO's Coup Attempt in Turkey. Retrieved from https://www.aa.com.tr/uploads/T empUserFiles/pdf/feto_en_sn.pdf

Anadolu Agency. (2018, July 16). Turki, Indonesia sepakat bersihkan guru terkait FETO di 9 sekolah. Retrieved January 11, 2020, from https://www.aa.com.tr/id/headlin e-hari/turki-indonesia-sepakatbersihkan-guru-terkait-feto-di-9sekolah/1205265

Anadolu Agency. (2019). NU kerjasama pendidikan dengan Maarif Foundation Turki. Retrieved January 11, 2020, from https://www.aa.com.tr/id/dunia/ nu-kerjasama-pendidikan-denganmaarif-foundation-turki/1541193

Angey, G. (2018). The gülen movement and the transfer of a political conflict from Turkey to Senegal. Politics, Religion and Ideology, 19(1), 53-68.

https://doi.org/10.1080/2156768 9.2018.1453256

BBC News Indonesia. (2016, September 23). Murid dan pengelola "sekolab Gülen" di berbagai negara merasakan tekanan. Retrieved from https://www.bbc.com/indonesia/ dunia/2016/09/160922_dunia_se kolah_Gülen_turki

Chaudhary, A. R., \& Moss, D. M. (2019). Suppressing transnationalism: bringing constraints into the study of transnational political action. Comparative Migration Studies, 7(1). https://doi.org/10.1186/s40878019-0112-z

Cooley, A. (2019). The International Dimensions of the New Transnational Repression. Retrieved from https://www.csce.gov/sites/helsin kicommission.house.gov/files/CO OLEY Alex - Testimony.pdf

Cooley, A., \& Heathershaw, J. (2017). Dictators without borders: Power and money in Central Asia. In Dictators Without Borders: Power and Money in Central Asia. https://doi.org/10.1093/ia/iix172

Detiknews. (2016a, July 29). Dituding Turki Terkait Gülen, Kepsek Kharisma Bangsa: Kami Tak Ada Hubungan Apa pun dengan Turki. Retrieved January 10, 2020, from https:// news.detik.com/berita/d3264419/kepsek-kharisma-bangsakami-tak-ada-hubungan-apa-pundengan-turki

Detiknews. (2016b, July 29). Turki Soroti Sekolah Gülen, Mendikbud: Kontrak dengan PASIAD Selesai Tahun Lalu, Sekolah Tetap Buka. Detik.Com. Retrieved from https://news.detik.com/berita/32 64614/mendikbud-kontrakdengan-pasiad-selesai-tahun-lalusekolah-tetap-buka 
Eurasia. (2016, September 12). Turkey: Effort to Force Closure of Gülen Schools Falling Flat in Eurasia. Retrieved from https://eurasianet.org/turkeyeffort-force-closure-Gülenschools-falling-flat-eurasia

European Commission for Democracy Through Law. (2016). Turkey: Emergency Decree Laws 667-674. Retrieved from https://www.venice.coe.int/webfo rms/documents/default.aspx?pdffi le $=$ CDL-REF(2016)061-e

Garvey, J. I. (1980). Repression of the Political Emigre. The Underground to International Law: A Proposal for Remedy. The Yale Law Journal. https://doi.org/10.2307/795858

Gibney, M. J. (2013). Should citizenship be conditional? the ethics of denationalization. Journal of Politics. https://doi.org/10.1017/S002238 1613000352

Jawa Pos. (2017, December 21). Tegas, Indonesia Deportasi Warga Negara Turki tak Berdokumen! Retrieved January 10, 2020, from https://www.jawapos.com/interna sional $/ 21 / 12 / 2017 /$ tegasindonesia-deportasi-warga-negaraturki-tak-berdokumen/

Jenkins, G. H. (2009). Between Fact and Fantasy: Turkey's Ergenekon Investigation. Retrieved from www.silkroadstudies.org

Journalists and Writers Foundation. (2017). Assault on Education in Turkey and Abroad. Retrieved from http://sethemfree.com/wpcontent/uploads/2017/10/Educat
ion-Report-in-Turkey-2017.pdf

Journalists and Writers Foundation. (2018). ESCAPING THE WITCH HUNT The Right to Leave] FROM TURKEY \& AROUND THE $W O R L D$. Retrieved from www.jwf.org

Journalists and Writers Foundation. (2019). Erdoğan's Policies: A Threat to Global Peace \& Security. Retrieved from http://jwf.org/jwf/wpcontent/uploads/2019/10/JWFReport-2019-Erdoğans-Policies-AThreat-to-Global-Peace-andSecurity.pdf

Kassem, R. (2014). Passport revocation as proxy denaturalization: Examining the yemen cases. Fordham Law Review.

Kemlu.go.id. (2019). Kunjungan Delegasi Muhammadiyah ke Turki. Retrieved January 11, 2020, from https://kemlu.go.id/ankara/id/ne ws/3539/kunjungan-delegasimuhammadiyah-ke-turki

Komnasham.go.id. (2016). Komnas HAM Diminta Lindungi Warga Negara Turki di Indonesia Komnas HAM. Retrieved January 10, 2020, from

https://www.komnasham.go.id/in dex.php/news/2016/11/22/41/k omnas-ham-diminta-lindungiwarga-negara-turki-diindonesia.html

Kompas.com. (2016, July 29). Tanggapan Kemenlu Terkait Permintaan Turki Tutup 9 Sekolah. Retrieved July 10, 2020, from https:// nasional.kompas.com/rea d/2016/07/29/10493791/tanggap 
an.kemenlu.terkait.permintaan.turk i.tutup.9.sekolah.

Liputan6.com. (2018). Dituduh Bantu

Teroris, Ayah Bintang NBA

Dihukum 15 Tahun Penjara.

Retrieved January 11, 2020, from https://www.liputan6.com/bola/r ead/3563426/dituduh-bantuteroris-ayah-bintang-nba-dihukum15-tahun-penjara

McSherry, J. P. (2005). Predatory States: Operation Condor and Covert War in Latin America. In Rowman \& Littlefield.

https://doi.org/10.5860/choice.43 $-4297$

Moss, D. M. (2016). Transnational Repression, Diaspora Mobilization, and the Case of the Arab Spring. Social Problems. https://doi.org/10.1093/socpro/s pw019

Nugraha, G. A. (2016). Gülenist

Tentacles and Indonesian

Authorities. World Bulletin.

Retrieved from https://www.worldbulletin.net/ne ws-analysis/Gülenist-tentaclesand-indonesian-authoritiesh176037.html

Osman, M. N. M. (2008). Towards a Middle Way Islam in Southeast Asia: Controbutions of the Gülen Movement. Studia Islamika. https://doi.org/10.15408/sdi.v15i 3.525

Ozkan, B. (2016). Turkey's Kamikaze Coup Attempt: Why Now and What Next? Huffington Post. Retrieved from https://www.huffpost.com/entry/ turkey-coup_b_11033324
Pujayanti, A. (2009, July). Hubungan Bilateral Turki-Indonesia: PascaKegagaln Kudeta Militer. Majalah Info Singkat Puslit DPR RI.

Retrieved from www.pengkajian.dpr.go.id

Republika.co.id. (2016, July 29). Turki

Minta Indonesia Tutup Sekolah Terkait Gülen, Ini Kata Kemenlu.

Retrieved from https:// nasional.republika.co.id/b erita/ob2197330/turki-mintaindonesia-tutup-sekolah-terkaitGülen-ini-kata-kemenlu

Reynolds, M. A. (2016, September 28). Damaging Democracy: The US, Fethullah Gülen, and Turkey's Upheaval. Foreign Policy Research Institute. Retrieved from https://www.fpri.org/article/2016 /09/damaging-democracy-u-sfethullah-Gülen-turkeys-upheaval/

Rohmawan, F. (2011). Prpblematika Pelaksanaan Sekolah Bertaraf Internasional (SBI): Sebuah Studi Kasus di Sragen Bilingual Boarding School (SBBS). Univsersitas Sebelas Maret.

Shain, Y. (1990). The Shifting Character of Loyalty: The Dilemma of Exiles in Times of War. Comparative Politics. https://doi.org/10.2307/421964

Shain, Y. (2005). The frontier of loyalty: Political exiles in the age of the nation-state. In The Frontier of Loyalty: Political Exiles In The Age of The Nation-State. https://doi.org/10.2307/2622469

Soldatov, A., \& Borogan, I. (2019). The Compatriots: Dissidents, Hackers, Oligarchs, and Spies--The Story of 
Russia's Uncontrollable Emigres. New York: World Affairs.

Stockholm Center for Freedom. (2017). Erdoğan's Long Arms, The Case of Malaysia: Turkey's Witch-Hunt Abduction Abroad (Vol. 26). https://doi.org/10.1017/S096318 0117000214

Stockholm Center for Freedom. (2019). Erdoğan's Maarif Foundation has taken over 191 Gülen-linked schools in 21 countries, says chair Stockholm Center for Freedom. Retrieved January 11, 2020, from https:/ / stockholmcf.org/Erdoğan s-maarif-foundation-has-takenover-191-Gülen-linked-schools-in21-countries-says-chair/

TangerangOnline.id. (2016, July 29). Dituding Turki Terkait Gülen, Kharisma Bangsa Pamulang: Menteri RI tak Tutup Sekolah Kita. Retrieved January 10, 2020, from

https:/ / tangerangonline.id/2016/ 07/29/dituding-turki-terkaitGülen-kharisma-bangsa-pamulangmenteri-ri-tak-tutup-sekolah-kita/

Tempo.co. (2016, July 30). Begini Akhir Hubungan SBBS Sragen dengan PASIAD Asal Turki. Retrieved January 11, 2020, from https:/ / nasional.tempo.co/read/7 91833/begini-akhir-hubungansbbs-sragen-dengan-pasiad-asalturki

The National. (2016). Turkey puts pressure on foreign countries to close Gülen-linked schools. Retrieved from https://www.thenational.ae/world / turkey-puts-pressure-on-foreigncountries-to-close-Gülen-linkedschools-1.157615
TRT Melayu. (2018). Turki Jalin Kerjasama dengan Indonesia di Bidang Pendidikan. Retrieved January 11, 2020, from Turkey Radio and Television website: https://www.trt.net.tr/melayu/asi a-tenggara/2018/12/15/turkijalin-kerjasama-dengan-indonesiadi-bidang-pendidikan-1107454

Turkish Embassy in Jakarta. (2016). Press Release from The Embassy of The Republic of Turkey. Retrieved January 7, 2020, from http:/ /jakarta.emb.mfa.gov.tr/Mis sion/ShowAnnouncement/310458

Turkish Minute. (2016). Two Teachers among Five Killed in Terrorist Attack in Mogadishu. Retrieved from https://www.turkishminute.com/ 2016/03/31/two-turkish-teachersamong-five-killed-gun-attackmogadishu/

Turkish National Police Academy. (2019). FETO As an International Threat (Vol. 4). Retrieved from https://www.pa.edu.tr/Upload/ed itor/files/FETÖ AS AN INTERNATIONAL THREAT.pdf

World Bulletin. (2016). Turkish Foundation Takes Over FETO Schools in Chad. Retrieved from https://www.worldbulletin.net/afr ica/turkish-foundation-takes-overfeto-schools-in-chad-h180397.html

Yavuz, M. H., \& Koç, R. (2016). The Turkish coup attempt: The Gülen movement vs. The state. Middle East Policy. https://doi.org/10.1111/mepo.12 239 
Islamic Insights 2019; Vol. I No. 2, December 2019, pp. 1-15

ISSN: 2684-7383

Cite this as:

Faishal, M. Aminudin. Santri's Community in Political Change: Historical Interpretive. Islamic Insights Journal. 2019: Vol. 1(2): PP 1-19. 